\title{
A cost comparison of warfarin vs enoxaparine or new oral anticoagulants used for the treatment of patients with pulmonary embolism
}

\author{
Murat TÜRK ${ }^{1}$ \\ Yağmur ALDAĞ $\breve{L}^{2}$ \\ Ipek Kıvılcım OĞUZÜLGEN ${ }^{2}$ \\ Numan EKiM ${ }^{2}$
}

${ }^{1}$ Clinic of Chest Diseases, Yerkoy State Hospital, Yozgat, Turkey

${ }^{1}$ Yerköy Devlet Hastanesi, Gögü̈s Hastalıkları Kliniği, Yozgat, Türkiye

2 Department of Chest Diseases, Faculty of Medicine, Gazi University, Ankara, Turkey

${ }^{2}$ Gazi Üniversitesi Tıp Fakültesi, Göğüs Hastalıkları Anabilim Dalı, Ankara, Türkiye

\section{SUMMARY}

A cost comparison of warfarin vs enoxaparine or new oral anticoagulants used for the treatment of patients with pulmonary embolism

Introduction: Recently, novel oral anticoagulants (rivaroxaban, dabigatran, apixaban) have been approved for pulmonary embolism (PE) treatment. Each anticoagulant used during initial and maintenance therapy has direct and indirect costs for healthcare systems. Demonstrating the costs of treatment with different anticoagulants in a specific patient group will be helpful for clinicians determining treatment strategies.

Materials and Methods: Retrospective data of 118 patients with PE who were hospitalized and treated with warfarin for at least 3 months were evaluated. Direct medical and nonmedical costs were calculated. True costs with warfarin and modeled costs with rivaroxaban, dabigatran, apixaban and enoxaparine were calculated and compared for maintenance therapy. Estimated costs of initial and maintenance treatment with different anticoagulants were compared for the 49 patients with low complication risk.

Results: The average total cost of maintenance treatment with warfarin was found to be higher than the novel oral anticoagulants (€286.5 for warfarin, €233.3 for rivaroxaban, €231.7 for dabigatran, and €229.6 for apixaban). In patients with low complication risk, who could be treated without hospitalization, alternative treatment regiments were found to cost less than warfarin treatment (€883.1 for warfarin, €254.3 for rivaroxaban, €238 for apixaban, and €810.6 for enoxaparine).

Conclusion: Maintenance therapy with novel oral anticoagulant costs less than warfarin treatment. In patients with lower complication risks, alternative regimens that do not require hospitalization could cost less.

Key words: Economics, pharmaceutical, pulmonary embolism, new oral anticoagulants

\section{ÖZET}

Akut pulmoner embolide varfarin ile enoksaparin veya yeni oral antikoagülanların kullanımının maliyetlerinin karşılaştırılması

Giriș: Yeni nesil oral antikoagülanlar (rivaroksaban, dabigatran, apiksaban) yakın zamanda pulmoner emboli (PE) tedavisi için onay almış ilaçlardır. Başlangıç ve idame tedavisinde kullanılan

\section{Yazışma Adresi (Address for Correspondence)}

Dr. Murat TÜRK

Yerköy Devlet Hastanesi, Göğüs Hastalıkları Kliniği, YOZGAT - TURKEY

e-mail: mrttrk@gmail.com 
ilaçların doğrudan ve dolaylı maliyetleri bulunmaktadır. Spesifik bir hasta grubunda ortaya çıkan bu maliyetlerin gösterilmesi, klinisyenlere tedavi seçimlerinde yardımcı olabilecektir. Bu çalışmada PE tedavisinde kullanılabilecek farklı antikoagülanlarla ortaya çıkan maliyetlerin karşılaştırılması amaçlanmıştır. Ayrıca düşük komplikasyon riski bulunan hasta grubu belirlenerek bu grupta başlangıç (ilk 5-10 gün) ve idame (başlangıç tedavisinin bitiminden itibaren) tedavi maliyetleri analiz edilmiştir.

Materyal ve Metod: PE tanısı ile hastane yatışı yapılan ve en az 3 ay varfarin tedavisi alan 118 hastanın verileri retrospektif olarak değerlendirildi. Doğrudan medikal ve nonmedikal maliyetler belirlendi. idame tedavide varfarin kullanımına bağlı gerçek maliyetler ve rivaroksaban, dabigatran, apiksaban ve enoksaparin kullanımına bağlı tahmini maliyetler belirlendi ve karşılaştırıldı. Düşük komplikasyon riski bulunan 49 hastada ortaya çıkabilecek tahmini başlangıç ve idame tedavi maliyetleri belirlenerek karşılaştırıldı.

Bulgular: Varfarin ile idame tedavisine devam eden hastalarda ortaya çıkan ortalama toplam maliyet, yeni nesil oral antikoagülanlara göre yüksek bulundu (varfarin için $286.5 €$, rivaroksaban için $233.3 €$, dabigatran için $231.7 €$ ve apiksaban için $229 €$ ). Hastane yatışı olmadan tedavi edilebilecek olan düşük komplikasyon riskine sahip hastalarda kullanılabilecek alternatif tedavi seçenekleri ile ortaya çıkan maliyetler, varfarin tedavisine göre daha düşük bulundu (varfarin için 883.1 €, rivaroksaban için $254.3 €$, apiksaban için $238 €$ ve enoksaparin için $810.6 €)$.

Sonuç: Idame tedavide yeni nesil oral antikoagülanlarla ortaya çıkabilecek maliyetler daha düşük bulunmuştur. Hastane yatışı yapımayabilecek düşük komplikasyon riskine sahip hastalarda tercih edilecek alternatif tedavi seçenekleri daha düşük maliyetler ortaya çıkacaktır.

Anahtar kelimeler: ilaç maliyetleri, pulmoner emboli, yeni oral antikoagülanlar

\section{INTRODUCTION}

Pulmonary embolism (PE) is a common clinical condition with high mortality and morbidity unless treated with appropriate therapy. It has a mortality of $25 \%-30 \%$ when untreated compared with $2 \%-8 \%$ in treated cases. Initial treatment requires therapeutic dosages of unfractionated heparin (UFH), low molecular weight heparin (LMWH), fondaparinux or new oral anticoagulants (rivaroxaban, apixaban) (1-3). Dabigatran is also approved for the treatment of $\mathrm{PE}$, it requires 7 to 10 days of $\mathrm{UFH}$ or $\mathrm{LMWH}$ treatment initially. In clinical practice, initial treatment (first 5-10 days) with parenteral anticoagulants following hospitalization, bridging to warfarin as maintenance therapy (from end of initial treatment), is the mostly preferred treatment option $(4,5)$. Current guidelines suggest that patients with an in-hospital mortality risk less than $1 \%$ can also be treated in outpatient settings $(4,6)$.

Each therapy used during initial or maintenance treatment periods causes direct and indirect costs for the healthcare system, the majority of which are due to hospitalization. In a study using US data, the average cost per patient for hospitalization due to PE and 12 months of follow-up was found to be $\$ 16.644$, and hospital expenses were reported to make $87.5 \%$ of the costs (7).

In this study, we aimed to determine and compare the costs of initial and maintenance therapy of PE with different anticoagulant strategies. In order to evaluate these costs, we modeled a group of patients that were hospitalized and treated with warfarin for PE. In a group of patients with low risk of complications (those with low simplified pulmonary embolism severity index score) who could be treated without hospitalization, we also compared true and estimated costs for hospitalization and outpatient clinic follow-up.

\section{MATERIALS and METHODS}

\section{Patient Selection}

Data of 636 patients who were followed up in a university hospital between February 2004 and January 2014 were retrospectively evaluated. In total, 118 patients that were hospitalized and treated for $\mathrm{PE}$, who were treated with warfarin for at least 3 months on maintenance therapy, who had no kidney diseases or active malignancy, and whose INRs were controlled only at our clinic, at regular intervals, were included in the study (Figure 1). Any patient whose treatment was discontinued for reasons other than clinically important minor bleeding or high INR, or who had major bleeding, were excluded from the study.

\section{Data Collection}

Demographic features (sex, age, marital status, and occupation), comorbidities, and follow-up data were recorded. For every patient, the number of admissions during their follow-up period was established. For those patients whose treatment was planned to be life long, data were recorded for a 1-year period. Clinically important minor bleedings were recorded. 


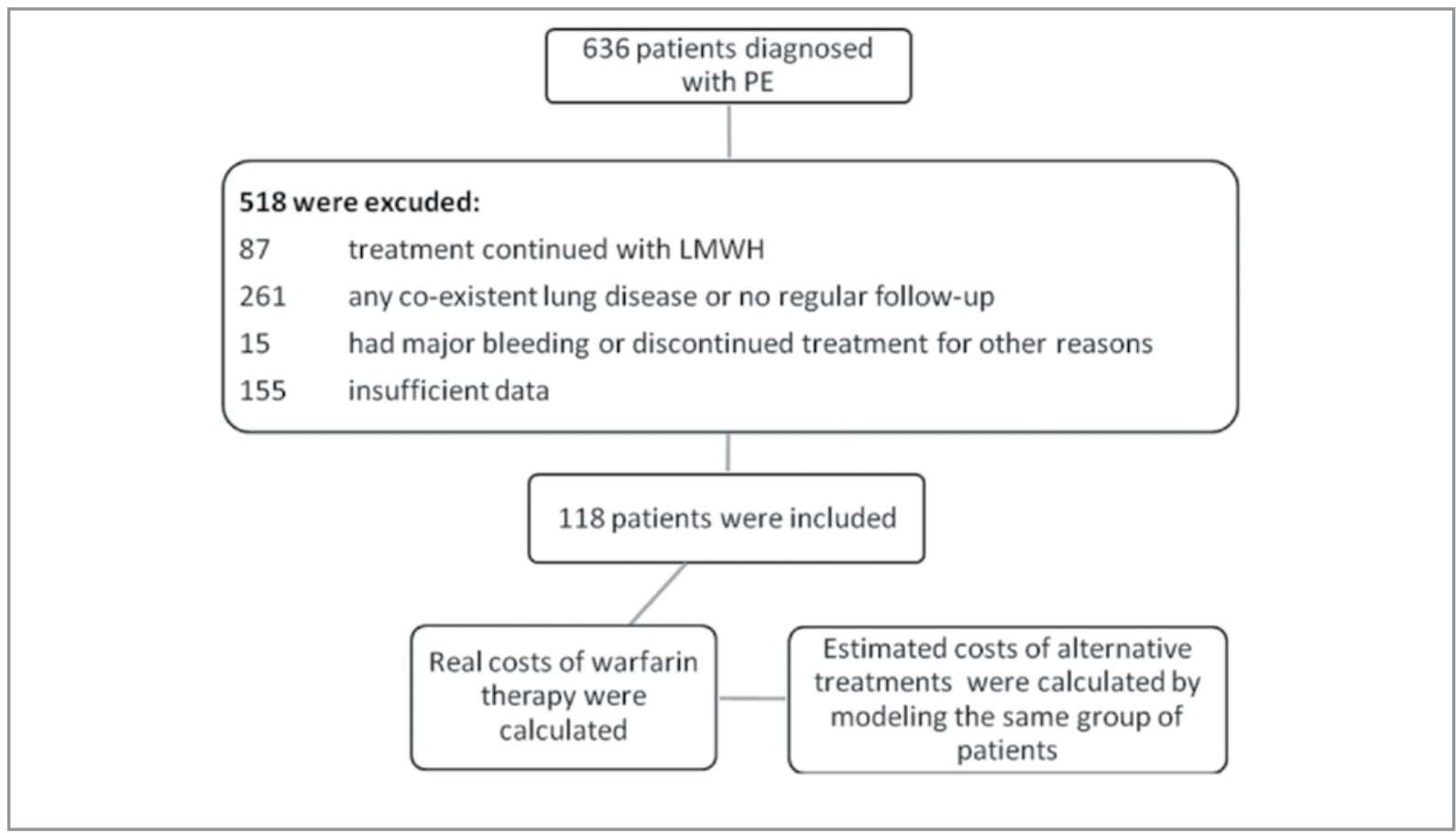

Figure 1. Patient selection and modeling.

\section{Costs Analysis and Model Assumptions}

Direct medical and nonmedical costs were calculated based on up-to-date values for cost estimation. The cost of hospitalization at the time of diagnosis was derived from the statistics unit in our hospital. Current pharmacy costs were derived from data of the "Turkish Ministry of Health, General Directorate of Pharmaceuticals and Pharmacy"; costs of admission to outpatient clinic for chest diseases were derived from data of "Application Statement on Health" and transportation costs were derived from the schedule of prices of the "Ankara Chamber of Minibus Drivers." In order to exchange Euro $(€)$ to Turkish Lira (TL) for hospitalization expenses, exchange rates at the time of patient admission were used; for other costs, the exchange rate of $€ 1=T L 2.8521$ was used. Qualityadjusted life-years and costs related to productivity loss were not calculated. Instead, average absences from work per year secondary to outpatient clinic admissions were calculated for working patients.

Pharmacy costs were based on the Coumadin ${ }^{\circledR} 5 \mathrm{mg}$ tablet for warfarin, the Xarelto ${ }^{\circledR} 15 \mathrm{mg} / 20 \mathrm{mg}$ tablets for rivaroxaban, the Pradaxa ${ }^{\circledR} 150 \mathrm{mg} 60$ tablet for dabigatran, the Eliquis ${ }^{\circledR} 5 \mathrm{mg} 60$ tablet for apixaban and the Clexane ${ }^{\circledR} 6000$ anti-Xa IU/0.6 mL injector for enoxaparine.

\section{Maintenance treatment costs}

The estimated costs of maintenance treatment with rivaroxaban, dabigatran, apixaban or enoxaparine in a population with the same clinical features were calculated and compared by modeling the 118 patients under warfarin treatment. Since no complications occurred in selected patient group and no other hospitalization or routine controls were needed, only pharmacy costs were calculated for rivaroxaban, dabigatran, apixaban and enoxaparine.

\section{Initial and maintenance treatment costs with low sPESI score}

Hospitalization, pharmacy, admissions to outpatient clinics, and transportation costs were calculated for the warfarin therapy group. For all patients, simplified PE severity index (SPESI) scores were calculated. Subgroup analysis was performed for those patients who could be treated in outpatient setting without hospitalization according to $\mathrm{SPESI}$ scores $(\mathrm{sPESI}=0)$ ). For the modeled alternative anticoagulation strategies, estimated pharmacy costs for rivaroxaban (Initial treatment: $2 \times 15 \mathrm{mg}$ for 21 days; maintenance treatment: $1 \times 20 \mathrm{mg}$ ), apixaban (Initial treatment: $2 \times$ $10 \mathrm{mg}$ for 10 days; maintenance treatment: $2 \times 5 \mathrm{mg}$ ) and enoxaparine (Initial treatment: $2 \times 0.6 \mathrm{~mL}$ for 5 days; maintenance treatment; $1 \times 0.6 \mathrm{~mL}$ ) were 
calculated and compared because no hospitalization or routine follow-up was required in this selected patient population. Since 7 to 10 days of dual therapy with UFH or $\mathrm{LMWH}$ is needed for dabigatran initially, it was not included in this calculation.

\section{Statistical Analysis}

SPSS 17.0 (SPSS Inc., Chicago, IL, USA) was used for statistical analysis. Central tendency and dispersion of data were shown as mean \pm standard deviation or median (interquartile range). In addition, the 95\% confidence interval was calculated for cost data. As the numerical values related to costs did not have a normal distribution, unless stated otherwise, they were expressed as median (interquartile range) or percent.

When comparing continuous variables, an independent sample $t$ test was used for parametric values and the Mann-Whitney $U$ test for nonparametric values. The $p$ value of $<0.05$ was considered to be significant.

This study was approved by the institutional review board of Gazi University (26.205.2014/272).

\section{RESULTS}

\section{Patient Population}

Median age of the whole population was 61.5 years (19-86) and women represented $51.7 \%$ of patients (Table 1). The treatment period related to PE was 205.5 (172.8-325) days. During this treatment period, the average number of outpatient clinic admissions was $15.4 \pm 5.9$ per patient. During follow-up, INR results were in the therapeutic range (2.0-3.0) for only $50.5 \%$ of time in the whole group. There were seven clinically significant minor bleeding episodes, including three hemoptyses, three superficial echymoses, and one epistaxis. Medical therapy was discontinued by the doctor for a short time as the bleeding continued.

\section{Costs Analysis}

\section{Costs on maintenance treatment}

The median pharmacy cost for warfarin usage was calculated as €15.9 (10.5-22.4) for the maintenance period. The cost of outpatient clinic admission was $€ 240.5$ (189-326.4) per patient (Table 2). Sex, age, comorbidity and its type, complications, and occupation had no effect on the average number of outpatient clinic admissions, so changes in these
Table 1. General characteristics and follow-up data of all patients

\begin{tabular}{|lc|}
\hline & $\mathrm{n}=118$ \\
\hline $\begin{array}{l}\text { Median age (min-max) } \\
\text { Femaler, } \mathrm{n}(\%)\end{array}$ & $61.5(19-86)$ \\
Comorbid disease, $\mathrm{n}(\%)$ & $61(51.7)$ \\
$\quad$ Yes & $65(55.6)$ \\
$\quad$ No & $52(44.4)$ \\
Comorbidities, $\mathrm{n}(\%)$ & \\
$\quad$ Cardiac & $50(42.7)$ \\
$\quad$ Endocrine & $19(16.2)$ \\
$\quad$ Neurological & $2(1.7)$ \\
$\quad$ Respiratory & $6(5.1)$ \\
$\quad$ Rheumatological & $3(2.6)$ \\
$\quad$ Malignancy * & $4(3.4)$ \\
Median duration of treatment, & 205.5 \\
days (25-75\% IQR) & $(172.8-325)$ \\
Number of outpatient clinic admissions & $15.4 \pm 5.9$ \\
\hline $\begin{array}{l}\text { Min= Minimum, Max= Maximum, IQR interquartile range. } \\
* \text { Those without active malignancy. }\end{array}$ \\
\hline
\end{tabular}

variables caused no significant difference to the average annual cost of outpatient clinics ( $p>0.05$ ). At the outpatient clinic, the total transportation cost was €19.6 (15.4-26.6) per patient (Table 2). The total cost of pharmacy, admission to outpatient clinic, and transportation for warfarin maintenance treatment was $€ 286.5$ (225-369.2).

Considering the alternative treatments, the estimated cost per patient of maintenance treatment was calculated as €233.3 (196-368.9) with rivaroxaban, $€ 231.7$ (194.8-366.5) with dabigatran, €229.6 (193.1-363.2) with apixaban and €800.9 (673.21266.6) with enoxaparine (Table 2). Only pharmacy costs were calculated for these treatment options that did not require routine follow-up and showed no complications in the selected group of patients. For patients under maintenance treatment with warfarin, alternative therapies with rivaroxaban, dabigatran or apixaban significantly decreased the costs approximately by $19 \%$, and therapy with enoxaparin significantly increased the cost approximately by $180 \%$.

\section{Costs on initial and maintenance treatment for low sPESI score}

There were 49 patients with $s P E S I=0$. The mean true hospitalization cost of initial treatment for these 
Table 2. True and estimated costs of maintenance treatment in the whole patient population

\begin{tabular}{|c|c|c|c|}
\hline \multirow{2}{*}{$n=118$} & \multicolumn{3}{|c|}{ True costs based on maintenance treatment, $€$} \\
\hline & Mean \pm SD & Median (IQR) & $95 \% \mathrm{Cl}$ \\
\hline Warfarin pharmacy & $17.4 \pm 11$ & $15.9(10.5-22.4)$ & $15.4 ; 19.5$ \\
\hline Outpatient clinic admission & $263.8 \pm 100.7$ & $240.5(189-326.4)$ & $245.5 ; 282.2$ \\
\hline Transportation & $21.5 \pm 8.2$ & $19.6(15.4-26.6)$ & $20 ; 23$ \\
\hline \multirow[t]{2}{*}{ Total } & $306.1 \pm 113.9$ & $286.5(225-369.2)$ & $284.8 ; 327.5$ \\
\hline & \multicolumn{3}{|c|}{ Estimated costs based on maintenance treatment, $€$} \\
\hline Rivaroxaban pharmacy* & $258.8 \pm 106.3$ & $233.3(196-368.9)$ & $239.4 ; 278.2$ \\
\hline Dabigatran pharmacy** & $257.1 \pm 105.6$ & $231.7(194.8-366.5)$ & $237.9 ; 276.36$ \\
\hline Apixaban pharmacy*** & $254.8 \pm 104.6$ & $229.6(193.1-363.2)$ & $235.7 ; 273.9$ \\
\hline Enoxaparine pharmacy $* * * *$ & $888.5 \pm 364.9$ & $800.9(673.2-1266.6)$ & $822 ; 955.1$ \\
\hline
\end{tabular}

patients was €577.3 (442.7-888.3) per patient. These patients can also be treated at outpatient settings without hospitalization, so they were assumed to be treated with rivaroxaban $2 \times 15 \mathrm{mg}$ for 21 days as initial and $1 \times 20 \mathrm{mg}$ as maintenance treatment, apixaban $2 \times 10 \mathrm{mg}$ for 10 days as initial and $2 \times 5$ $\mathrm{mg}$ as maintenance treatment or enoxaparine $2 \times 0.6$ $\mathrm{mL}$ for 5 days as initial and $1 \times 0.6 \mathrm{~mL}$ as maintenance treatment. The estimated costs were calculated (Table 3 ) and compared for these groups (Figure 2). In this group of patients with $\mathrm{sPESI}=0$, initial and maintenance treatment (without hospitalization) with rivaroxaban, apixaban and enoxaparine decreased the costs significantly by $\sim 71 \%, 73 \%$, and $8 \%$, respectively, compared with warfarin.

\section{Work Absences During the Follow-Up With Warfarin}

Forty-one patients who were actively working were admitted to outpatient clinics 574 times during their treatment period. From 2004 to 2014, working days comprised approximately $71 \%$ of a year; assuming that these patients took a half-day off, they were found to be absent from work for $4.7 \%$ of the year.

\section{DISCUSSION}

Our study demonstrated that, in Turkish healthcare settings, new oral anticoagulants are the most economical choices in maintenance therapy for PE. For patients who could be treated without hospitalization, costs of initial and maintenance treatment with rivaroxaban, apixaban or enoxaparine could cost lower than warfarin. In patients who were hospitalized for $\mathrm{PE}$, hospitalization was found to constitute approximately $75 \%$ of all costs from diagnosis to the end of treatment. In patients receiving warfarin treatment, outpatient clinic admissions were found to be responsible for approximately $90 \%$ of costs related solely to maintenance therapy.

Table 3. Costs of initial and maintenance therapy in patients with $\mathrm{SPESI}=\mathrm{O}$ with different anticoagulants

\begin{tabular}{|c|c|c|c|}
\hline $\begin{array}{l}\text { Anticoagulants } \\
n=49\end{array}$ & Mean \pm SD & Median (IQR) & $95 \% \mathrm{Cl}$ \\
\hline Warfarin* & $996.7 \pm 507.5$ & $883.1(623.3-1234.4)$ & $847.7 ; 1145.7$ \\
\hline Rivaroxaban ** & $283 \pm 102.8$ & $254.3(228.7-347.9)$ & $253.5 ; 312.6$ \\
\hline Apixaban*** & $266.4 \pm 101.2$ & $238(212.9-330.2)$ & $237.3 ; 295.4$ \\
\hline Enoxaparin $* * * *$ & $909.4 \pm 353.1$ & $810.6(722.9-1132.1)$ & $797.6 ; 1006.2$ \\
\hline \multicolumn{4}{|c|}{$\begin{array}{l}\mathrm{SD}=\text { Standard deviation, } \mathrm{IQR}=\text { Interquartile range, } \mathrm{Cl}=\text { Confidence interval. } \\
* \text { Includes hospitalization, outpatient clinic admission, pharmacy and transportation. } \\
* * \text { Rivaroxaban } 2 \times 15 \mathrm{mg} 21 \text { days as initial and } 1 \times 20 \mathrm{mg} \text { as maintenance treatment. } \\
* * * \text { Apixaban } 2 \times 10 \mathrm{mg} 10 \text { days as initial and } 2 \times 5 \mathrm{mg} \text { as maintenance treatment. } \\
* * * * \text { Enoxaparine sodium } 2 \times 0.6 \mathrm{~mL} 5 \text { days as initial and } 1 \times 0.6 \mathrm{~mL} \text { as maintenance treatment. }\end{array}$} \\
\hline
\end{tabular}




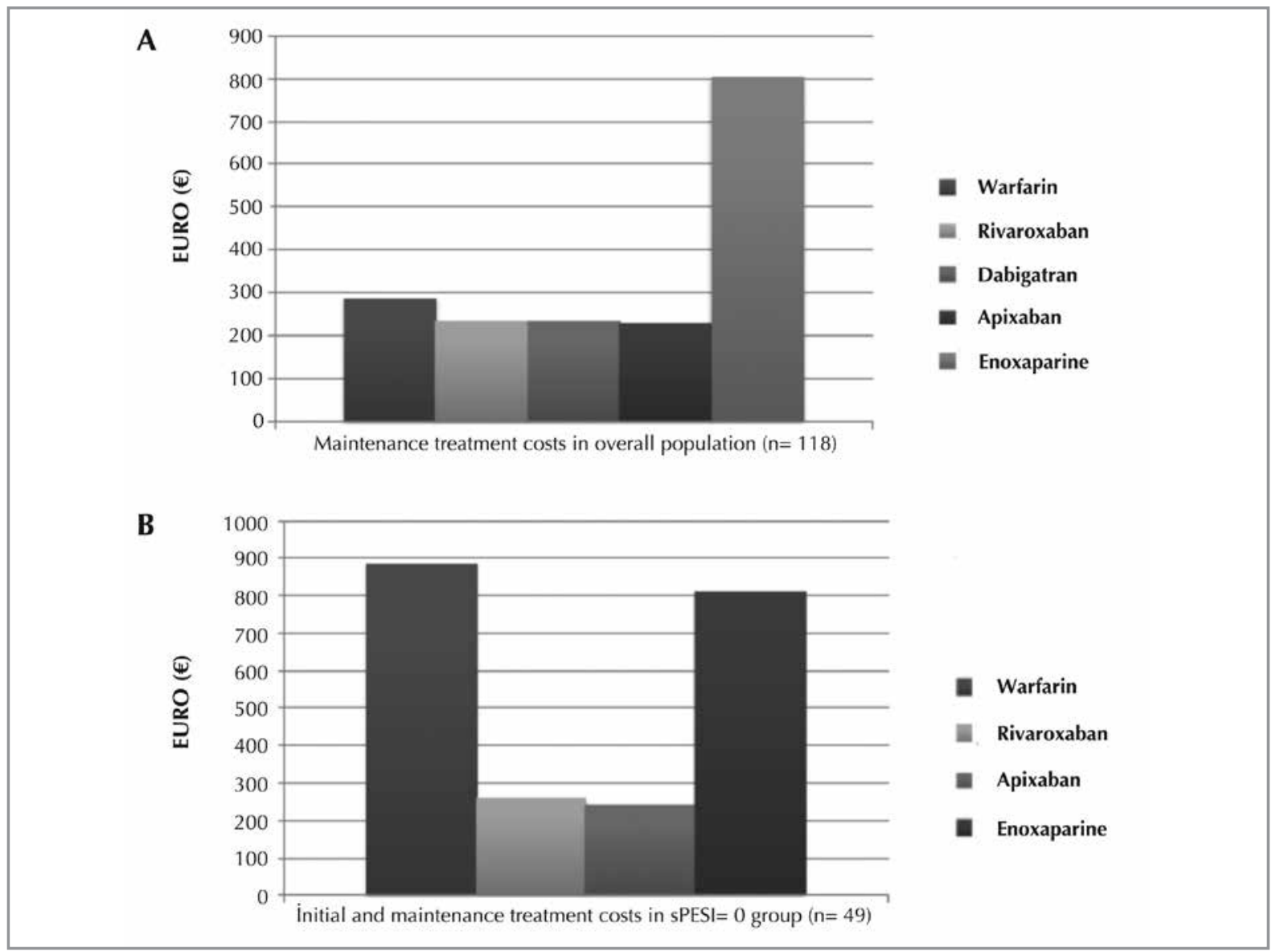

Figure 2. (A) Maintenance treatment costs of different anticoagulants in all patients. Rivaroxaban, dabigatran and apixaban cost lesser and enoxaparine costs higher than warfarin $(\mathrm{p}<0.05)$. There was no significant difference between costs of all three new oral anticoagulants. (B) Initial and maintenance treatment costs of different anticoagulants in patients with sPESI=0. Rivaroxaban and apixaban cost lesser than $(p<0.05)$, enoxaparine costs similar with warfarin $(p>0.05)$.

Warfarin, although cheap, requires regular clinic controls and INR follow-up; hence, it has nonpharmacy costs. In contrast, its alternatives, rivaroxaban, dabigatran, apixaban and enoxaparine, cause much higher pharmacy costs but they do not require routine follow-up. Based on our findings, changing warfarin treatment to alternative regimens other than enoxaparine in the maintenance period costs less in our country. When planning treatment, factors such as patient characteristics and preferences, as well as costs, are primarily important. Weitz and Gross provided a table to assist physicians in selecting anticoagulants based on patient characteristics (8). It stated that changing regimen is unnecessary in patients under warfarin treatment who are stabilized and had INR results in the therapeutic range. They showed that for patients with dyspepsia or upper gastrointestinal symptoms, creatinine clearance between 30 and $50 \mathrm{~mL} / \mathrm{min}$, and requests for a oncedaily regimen, rivaroxaban can be chosen.

The majority of costs related to initial treatment are revealed to be hospital expenses, so shortening length of stay (LOS) or decreased need for hospitalization may considerably decrease the burden on health expenses. The EINSTEIN-PE study demonstrated a 1-day decrease in median LOS for rivaroxaban compared to the low molecular weight heparin + warfarin regimen (9). In a study by Beckman et al., PE monotherapy with enoxaparine was shown to cause a 2-day decrease in the median LOS compared with the standard regimen (10). In a study in which Markov modeling was constructed based on the EINSTEIN-PE study, Lefebvre et al. (11) showed that rivaroxaban therapy costs $\$ 2.448$ per 
patient less than enoxaparine + warfarin therapy. In a similar study, Mody et al. stated $\$ 2,742$ less per patient (12).

Even though there has been no published study about the diagnosis and treatment costs of PE in our country, studies comparing these three pharmaceuticals for deep-vein thrombosis, PE, stroke, nonvalvular atrial fibrillation treatment, and orthopedic postoperative prophylaxis demonstrated that new oral anticoagulants were more costeffective than warfarin and enoxaparine (11-16). However, it should be remembered that costs related to hospitalization and complications are also included in these studies. For example, Mody et al. showed an economic gain of $17.1 \%$ with rivaroxaban compared with other agents and pointed out that approximately $90 \%$ of this gain was caused by the decreased LOS (12). When interpreting our results, one must consider that hospital costs are significantly lower in Turkey than in the US and EU. Our study showed an average hospitalization cost for PE of $\$ 717$ per patient compared with Spyropoulos et al. estimate of $\$ 14.146$ per patient in the US (7).

There are numerous scoring systems one can use in order to assess the complication risk related to PE and disease prognosis. Among these, the PESI or sPESI is the best validated $(17,18)$. Patients at low risk of serious complications according to the scoring system are accepted to be suitable for treatment without hospitalization $(4,17)$. An open-label randomized study by Aujesky et al. on outpatient treatment of low-risk patients diagnosed with PE showed that well-selected patients with a low PESI score can safely be treated at outpatient clinics (19). The ACCP guideline (The Updated 2012 American College of Chest Physicians Evidence-Based Clinical Practice Guidelines) and ESC 2014 guideline similarly state that well-selected patients can be treated at outpatient clinics, resulting in fewer unnecessary hospitalizations and up to $50 \%$ economical gain $(4,6)$. In a multicenter study, lowrisk patients were found to constitute $29.9 \%$ of patients with PE in our country (20). Thus, outpatient treatment can be considered in one-third of patients with $\mathrm{PE}$, improving not only patient comfort but also economical gain.

In this study, costs related to productivity loss were not calculated because of a lack of data. Only loss of work days was calculated based on outpatient clinic admissions for INR control, and a loss of $4.7 \%$ per year ( 17 days) was found. In a study by Page et al. (21), short-term disability per patient with PE was $56.4 \pm 3$ days, long-term disability $363.9 \pm 26.1$ days. The mean estimated lost wage per disability claim for PE was $\$ 18.514 \pm 1476$. The costs we have described will be a lot higher with the addition of these parameters.

Our study had some limitations; most importantly, we had data only for the group treated with warfarin and the other treatment results were calculated using assumptions based on the same group of patients. Because patients treated with enoxaparine were not regularly followed-up, real data could not be included in the study. Also, rivaroxaban and dabigatran had only recently been lisenced for PE treatment in our country at the time of the study, so there were no follow-up data about these drugs. Second, the results of this retrospective and singlecentered study that included only noncomplicated patients may not reflect real-world settings. Third, costs related to productivity loss were not included. In the future, studies also including these costs can calculate the true costs more accurately.

Finally, the costs used were derived from Turkish health-system data, making them lower compared with similar studies in the US or EU because healthcare is much cheaper in our country.

\section{CONCLUSIONS}

Cost data calculated in our study will be a guide for clinicians planning PE treatment. The findings suggest new oral anticoagulants cost less in maintenance therapy. We emphasize that anticoagulation choice in PE must be patient tailored. Increased referral to sPESI and similar scoring systems in clinical practice and outpatient treatment of patients with low risk for complications will provide up to $73 \%$ economical gain.

\section{AUTHORSHIP and CONTRIBUTORSHIP}

Murat Türk designed the study, analyzed data and drafted manuscript, Yağmur Aldağ collected data and drafted the manuscript, İpek Kıvılcım Oğuzülgen designed the study and edited the manuscript, Numan Ekim participated in the planning of the manuscript and critical review. 


\section{CONFLICT of INTEREST}

Murat Türk and Yağmur Aldağ have no conflicts of interest in connection with this article. İpek Kıvılcım Oğuzülgen is in the advisory board of and had lecture fees from Bayer Pharmeceticals and Boehringer Ingelheim. Numan Ekim is in advisory board of Bristol-Myers Squibb.

\section{ACKNOWLEDGEMENTS}

We thank Sefer Aycan, MD and Ahmet Uğur Demir, MD for their help in project design.

\section{REFERENCES}

1. The Columbus Investigators. Low-Molecular-Weight heparin in the treatment of patients with venous thromboembolism. N Eng J Med 1997;337:657-62.

2. EINSTEIN Investigators, Bauersachs $R$, Berkowitz SD, Brenner B, Buller HR, Decousus H, Gallus AS. Oral rivaroxaban for symptomatic venous thromboembolism. N Eng J Med 2010;363:2499-510.

3. Rudd KM, Phillips EL. New oral anticoagulants in the treatment of pulmonary embolism: efficacy, bleeding risk, and monitoring. Thrombosis 2013;2013;973710.

4. Kearon C, Akl EA, Comerota AJ, Prandoni P, Bounameaux H, Goldhaber SZ, et al. American College of Chest Physicians. Antithrombotic therapy for VTE disease: Antithrombotic Therapy and Prevention of Thrombosis, $9^{\text {th }}$ ed: American College of Chest Physicians Evidence-Based Clinical Practice Guidelines. Chest 2012;141(Supp/ 2): e419S-94S.

5. Arseven O, Sevinç C, Alataş F, Ekim N, Erkan L, Fındık S, et al. Türk Toraks Derneği Pulmoner Tromboembolizm Tanı ve Tedavi Uzlaşı Raporu. Turkish Thoracic Journal 2009;10 (Supp/ 11):S1-S49

6. Konstantinides SV, Torbicki A, Agnelli G, Danchin N, Fitzmaurice D, Galiè N, et al; The Task Force for the Diagnosis and Management of Acute Pulmonary Embolism of the European Society of Cardiology (ESC) Endorsed by the European Respiratory Society (ERS). 2014 ESC Guidelines on the diagnosis and management of acute pulmonary embolism: Eur Heart J Epub 2014 Aug 29.

7. Spyropoulos AC, Lin J. Direct medical costs of venous thromboembolism and subsequent hospital readmission rates: an administrative claims analysis from 30 managed care organizations. J Manag Care Pharm 2007;13:475-86.

8. Weitz II, Gross PL. New oral anticoagulants: which one should my patient use? Hematology Am Soc Hematol Educ Program 2012;2012:536-40.

9. EINSTEIN-PE Investigators. Oral rivaroxaban for the treatment of symptomatic pulmonary embolism. N Eng / Med 2012; 366:1287-97.
10. Beckman JA, Dunn K, Sasahara AA, Goldhaber SZ. Enoxaparin monotherapy without oral anticoagulation to treat acute symptomatic pulmonary embolism. Thromb Haemost 2003;89:953-8.

11. Lefebvre P, Coleman CI, Bookhart BK, Wang ST, Mody SH, Tran KN, et al. Cost-effectiveness of rivaroxaban compared with enoxaparin plus a vitamin $K$ antagonist for the treatment of venous thromboembolism. J Med Econ 2014; 17:52-64.

12. Mody SH, Huynh L, Zhuo DY, Tran KN, Lefebvre P, Bookhart B. A cost-analysis model for anticoagulant treatment in the hospital setting. J Med Econ 2014;17:492-98.

13. Lee S, Anglade MW, Pham D, Pisacane R, Kluger J, Coleman Cl. Cost-effectiveness of rivaroxaban compared to warfarin for stroke prevention in atrial fibrillation. Am J Cardiol 2012;110:845-51.

14. Seaman CD, Smith KJ, Ragni MV. Cost-effectiveness of rivaroxaban versus warfarin anticoagulation for the prevention of recurrent venous thromboembolism: a U.S. perspective. Thromb Res 2013;132:647-51.

15. Kleintjens J, Li X, Simoens S, Thijs V, Goethals M, Rietzschel $E R$, et al. Cost-effectiveness of rivaroxaban versus warfarin for stroke prevention in atrial fibrillation in the Belgian healthcare setting. Pharmacoeconomics 2013;31:909-18.

16. Gómez-Outes A, Avendaño-Solá C, Terleira-Fernández Al, Vargas-Castrillón E. Pharmacoeconomic evaluation of dabigatran, rivaroxaban and apixaban versus enoxaparin for the prevention of venous thromboembolism after total hip or knee replacement in Spain. Pharmacoeconomics 2014;32:919-36.

17. Jiménez D, Aujesky D, Moores L, Gómez V, Lobo IL, Uresandi $F$, et al. Simplification of the pulmonary embolism severity index for prognostication in patients with acute symptomatic pulmonary embolism. Arch Intern Med 2010;170:1383-9.

18. Chan CM, Woods C, Shorr AF. The validation and reproducibility of the pulmonary embolism severity index. J Thromb Haemost 2010;8:1509-14.

19. Aujesky D, Roy PM, Verschuren F, Righini M, Osterwalder I, Egloff M. Outpatient versus inpatient treatment for patients with acute pulmonary embolism: an international, open-label, randomised, non-inferiority trial. Lancet 2011;378:41-8.

20. Ozsu S, Ozlu T, Sentürk A, Uçar EY, Kırkıl G, Kadıoğlu EE; TUPEG Study Investigators. Combination and comparison of two models in prognosis of pulmonary embolism: results from Turkey Pulmonary Embolism Group (TUPEG) study. Thromb Res 2014;133:1006-10.

21. Page RL, Ghushchyan V, Gifford B, Read RA, Raut $M$, Bookhart BK, et al. Hidden costs associated with venous thromboembolism. J Occup Environ Med 2014;56:979-85. 